\title{
Tourism Mix Factor: Tourists' Travel Orientation in Choosing Types of Tourism Objects in Indonesia
}

\author{
Suliyanto ${ }^{1}$ \\ ${ }^{1}$ Management Departement, Economics and Business Faculty, Jenderal Soedirman University, Purwokerto, \\ Indonesia \\ Correspondence: Suliyanto, Management Departement, Economics and Business Faculty, Jenderal Soedirman \\ University, Purwokerto, HR. Boenyamin Street No. 708, Indonesia. Tel: 62-812-272-6400. E-mail: \\ suli_yanto@yahoo.com or suliyanto@unsoed.ac.id
}

Received: March 9, 2020

doi:10.5539/ass.v16n5p57
Accepted: March 28, $2020 \quad$ Online Published: April 30, 2020

URL: https://doi.org/10.5539/ass.v16n5p57

\begin{abstract}
The purpose of this research is to analyze the tourism mix factor that differentiates tourists in choosing the type of tourism object as a basis for formulating strategies to attract tourists. This research is a quantitative study using a survey approach. The sample in this study was 200 respondents, consisting of 100 respondents of natural tourism visitors and 100 respondents of artificial tourism visitors. The analytical tool used in this study was descriptive analysis and discriminant analysis with the Stepwise method. The results of this study indicate that the variables that differentiate tourists from choosing natural tourism objects and artificial tourism objects are coolness, advertisements, facilities, prices, locations, travel agents, tourist attractions, transportation facilities and infrastructure, and public hospitality. Tourists who choose natural tourism objects have more positive attitude concerned with the variables of coolness, price, public hospitality, the existence of a travel agency, and the availability of transportation facilities and infrastructure, while visitors who choose artificial tourism objects have more positive attitude or are more concerned with location variables, advertisements, tourist attractions, and completeness of the facilities. This study provides a clear guidance on the tourism mix factor that distinguishes domestic tourists in Indonesia which is still very limited and need further investigation.
\end{abstract}

Keywords: artificial tourism, natural tourism, travel orientation, tourism mix

\section{Introduction}

Tourism industry has a direct impact on a national economy of Indonesia (Tosun, 2002). In developing tourism industry will continue to play a very important role for the economy and will continue to grow, this is due to travel costs that become more affordable with the presence of low-cost flights, many arts and cultural festivals, improved transportation facilities and road infrastructure, and the growing development of tourism supporting sectors such as hotels and restaurants. This is in line with the opinion of Tsiotsou and Tsiotsou, (2010), which stated that in the era of globalization, tourism will become cheaper and faster because of low cost airlines and the development of information and communication technology. Tourism has become a necessity, Salimov (2018) said that in this era, traveling has developed into a social lifestyle for young generation.

In Indonesia, tourism has a very big role in the economic aspect as a foreign exchange earner. Tourism can be used as a tool to solve the problem of unemployment and poverty in developing countries (Dogra \& Gupta, 2012; Khuntia \& Mishra, 2016). Tourism will encourage the growth of Micro, Small and Medium Enterprises (MSMEs), In Indonesia, MSMs have played a significant role in economic sector (Suliyanto, 2013). The development of tourism in remote areas has proven able to encourage economic growth and preserve natural (Ritsma et al., 2010). Indonesia has various types of tourist attractions such as natural tourism, artificial tourism, and cultural tourism. In Indonesia, there are significant differences in domestic tourists in choosing tourism objects. It can be seen from the data from the Indonesian Ministry of Tourism that $52.66 \%$ of domestic tourists chose the type of natural tourism, $32.84 \%$ of artificial tourism and $14.50 \%$ of cultural tourism in 2017 . The significant difference between tourists in choosing the type of tourism is interesting to be studied. Mattila, (2004) stated that domestic tourists prefer choosing the type of natural tourism compared to artificial tourism objects and cultural tourism objects. Consumer behavior is a dynamic and eclectic in tourism marketing (Mattila, 2004). So, research on tourist behavior in selecting types of tourism attractions will continue to be interesting to be 
studied. Many previous studies have examined the factors that determine tourist visits intention to a tourist destination (Abuamoud, Libbin, \& Green, 2014; Khuong \& Nguyen, 2018), but specifically to examine the tourism mix factor that distinguishes domestic tourists in choosing the type of tourism object is still very limited.

The research was conducted in Banyumas Regency, because Banyumas Regency is one of the regencies in Central Java Province, Indonesia which has a variety of attractions both natural and artificial tourism. The national famous tourism object in Banyumas Regency is Baturraden tourism object. Around Baturraden tourism objects, there are now growing several tourism objects for both natural and artificial tourism, one of the artificial tourism objects is The Village Tourism object. Management of tourism objects, both its natural tourism objects and its artificial tourism objects compete each other to get visitors, so that competition between tourism objects is getting tougher. One of the indicators of the tourism development success is the number of visitors. The following the data presented on the number of tourist visitors to Banyumas Regency from 2014 to 2017.

Table 1. Number of Tourists Who Visit Tourism Obects in Banyumas Regency.

\begin{tabular}{lc}
\hline Year & Visitors (person) \\
\hline 2014 & 1.954 .873 \\
2015 & 1.784 .378 \\
2016 & 2.013 .992 \\
2017 & 2.111 .861 \\
\hline
\end{tabular}

Although tourism has a very important role for the economy, until now the tourism industry still facing various problems, one including the quality of services provided by the manager of tourism has not good enough yet. Whereas achieving tourist satisfaction is one of the most important factors in terms of managing various types of tourism (Marinoa, 2017), because tourist satisfaction will positively effects tourist loyalty (Hernandez et al., 2006; Coban, 2012). On the other hand, tourist dissatisfaction will reduce the intention of tourists to re-visit the tourism object, even it causes the negative word of mouth information.

Based on the description above, it can be seen that the tourism industry plays a very important role for the economy growth, and the increasing number of new tourism objects has led to tougher competition in creating tourism attractions to attract tourists. Beside, tourism management services in serving tourists has not yet good enough. As a result, this research needs to be done to analyze the tourism mix factor that differentiates tourists in choosing the type of tourist attraction as a basis for formulating strategies to attract tourists.

\section{Research Method}

This research was conducted in Banyumas regency, Central Java Province, Indonesia with the subject of the study of visitors to natural attractions, Baturraden and visitors to artificial attractions, The Village, in Banyumas Regency. The samples in this study were 200 respondents, consisting of 100 respondents of natural tourism visitors and 100 respondents of artificial tourism visitors, which were collected using the accidental sampling method. To analyze the tourism mix factors that differentiate tourists in choosing the type of tourist attraction, discriminant analysis tool is used in a phased method. Discriminant analysis is a method of analysis while the independent variable is a metric variable (interval or ratio), while the dependent variable is a non metric variable (nominal or ordinal).

The discriminant analysis model is using the following formula (Malhotra et al., 2006):

$\mathrm{D}=\mathrm{b}_{0}+\mathrm{b}_{1} \mathrm{X}_{1}+\mathrm{b}_{2} \mathrm{X}_{2}+\mathrm{b}_{3} \mathrm{X}_{3}+\ldots+\mathrm{b}_{\mathrm{n}} \mathrm{X}_{\mathrm{n}}$

In which:

$\mathrm{D}=$ Discriminant value

$\mathrm{b}=$ coefficient of discriminant of the independent variable

$\mathrm{X}=$ predictor variable or free variable

The steps to carry out discriminant analysis are as follows (Malhotra et al., 2006): a). Formulate the problem, b). Make estimation of the coefficient of discriminant function, c). Determine the level of significance of the discriminant function, d). Interpret the results of the analysis, e). Evaluate the validity of discriminant analysis. 


\section{Discussions of Results}

\subsection{Profile Respondents}

Analysis of the respondent profile was done using descriptive statistical analysis, which is presented in Table 2.

Table 2. Profile of Respondents for Visitors to Natural Tourism Objects and Visitors to Artificial Tourism Objects

\begin{tabular}{|c|c|c|c|c|c|}
\hline \multirow[t]{2}{*}{ Visitor's Profil } & \multirow[t]{2}{*}{ Detail } & \multicolumn{2}{|c|}{$\begin{array}{l}\text { Natural Tourism Object } \\
\text { (Baturraden) }\end{array}$} & \multicolumn{2}{|c|}{$\begin{array}{l}\text { Artificial Tourism Obect } \\
\text { (The Village) }\end{array}$} \\
\hline & & Total & Percentage & Total & Percentage \\
\hline \multirow{5}{*}{ Age } & 15 s.d. 24 year-old & 20 & 20 & 25 & 25 \\
\hline & 25 s.d. 34 year-old & 21 & 21 & 25 & 25 \\
\hline & 35 s.d. 44 year-old & 23 & 23 & 20 & 20 \\
\hline & $\geq 45$ year-old & 36 & 36 & 30 & 30 \\
\hline & Total & 100 & 100 & 100 & 100 \\
\hline \multirow{6}{*}{$\begin{array}{l}\text { Monthly } \\
\text { income }\end{array}$} & $\leq 5$ millions & 65 & 65 & 64 & 64 \\
\hline & $6-10$ millions & 29 & 29 & 24 & 24 \\
\hline & $11-15$ millions & 5 & 5 & 5 & 5 \\
\hline & $16-20$ millions & 1 & 1 & 3 & 3 \\
\hline & $>20$ millions & 0 & 0 & 4 & 4 \\
\hline & Total & 100 & 100 & 100 & 100 \\
\hline \multirow{8}{*}{$\begin{array}{l}\text { Information } \\
\text { source }\end{array}$} & Friend & 42 & 42 & 54 & 54 \\
\hline & Family & 21 & 21 & 20 & 20 \\
\hline & Brochure/Leaflet & 1 & 1 & 2 & 2 \\
\hline & Social Media & 12 & 12 & 21 & 21 \\
\hline & Printed Media & 0 & 0 & 1 & 1 \\
\hline & Internet & 6 & 6 & 0 & 0 \\
\hline & Others & 18 & 18 & 2 & 2 \\
\hline & Total & 100 & 900 & 100 & 100 \\
\hline \multirow{4}{*}{$\begin{array}{l}\text { Visitor's } \\
\text { companion }\end{array}$} & Family & 72 & 72 & 65 & 65 \\
\hline & Friend & 22 & 22 & 33 & 33 \\
\hline & Others & 6 & 6 & 2 & 2 \\
\hline & Total & 100 & 100 & 100 & 100 \\
\hline \multirow{6}{*}{$\begin{array}{l}\text { Most favorite } \\
\text { tourism } \\
\text { package }\end{array}$} & Outbond & 13 & 13 & 18 & 18 \\
\hline & Educational Tourism & 13 & 13 & 36 & 36 \\
\hline & Games & 12 & 12 & 17 & 17 \\
\hline & Specific interest & 16 & 16 & 17 & 17 \\
\hline & Others & 46 & 46 & 12 & 12 \\
\hline & Total & 100 & 100 & 100 & 100 \\
\hline \multirow{5}{*}{$\begin{array}{c}\text { Travel } \\
\text { orientation }\end{array}$} & Reducing boredom & 63 & 63 & 59 & 59 \\
\hline & Getting new experience & 16 & 16 & 21 & 21 \\
\hline & Health & 3 & 3 & 3 & 3 \\
\hline & Others & 18 & 18 & 17 & 17 \\
\hline & Total & 100 & 100 & 100 & 100 \\
\hline
\end{tabular}

Based on Table 2, it was known that the natural tourism object and the artificial tourism objects visited by visitors aged 45 year-old and over, they visited with friends or family. The average monthly income of visitors to Baturraden and The Village is $\leq$ Rp. 5 million per month. whichshows that the cost of traveling in Banyumas 
Regency is still affordable for visitor who earn $\leq$ Rp 5 million per month. Both Baturraden and The Village visitors mostly get information from friends, family and social media. So, promotion through word of mouth (WoM) is very effective to attract tourists. Most of the tourists who visitedBaturraden and The Village, came with family or friends in groups, and rarely perform the visitation. Travel packages that are expected by visitors in The Village are educational tours, while tourism packages that are expected by visitors to natural attractions Baturraden are others such as to see the beautiful scenery. Batturaden natural attractions are the most visited by respondents who come from regions outside Central Java Province, while the tourism objects made by The Village are mostly visited by respondents who come from the Banyumas Regency. This is because Baturraden's natural Batturaden natural attractions and The Village most visited by respondents who have a travel orientation to reduce boredom, after doing routine activities.

\subsection{Discriminant Analysis}

To differentiate the tourists orientation in visiting natural attractions and visiting artificial attractions, discriminant analysis is done using the Stepwise method. Based on discriminant analysis the following outputs can be obtained:

Table 3. Test of Equality of Group Means

\begin{tabular}{cccccc}
\hline Variabel & Wilks' Lambda & F & df1 & df2 & Sig. \\
\hline Beauty & .945 & 11.547 & 1 & 198 & .001 \\
Coolness & .919 & 17.387 & 1 & 198 & .000 \\
Completeness & 1.000 & .045 & 1 & 198 & .832 \\
Uniqueness & 1.000 & .066 & 1 & 198 & .798 \\
Price & .969 & 6.356 & 1 & 198 & .012 \\
Cost & .989 & 2.287 & 1 & 198 & .132 \\
Location & .993 & 1.400 & 1 & 198 & .238 \\
Nearness & 1.000 & .042 & 1 & 198 & .839 \\
Advertisement & .957 & 8.896 & 1 & 198 & .003 \\
Promotion & .978 & 4.352 & 1 & 198 & .038 \\
Service Hospitality & 1.000 & .009 & 1 & 198 & .923 \\
Public Hospitality & .987 & 2.639 & 1 & 198 & .106 \\
Safety & .995 & .904 & 1 & 198 & .343 \\
Travel Package & .984 & 3.223 & 1 & 198 & .074 \\
Experience & .988 & 2.349 & 1 & 198 & .127 \\
Atraction & .988 & 2.360 & 1 & 198 & .126 \\
Connection & .998 & .411 & 1 & 198 & .522 \\
Travel agency & .998 & .484 & 1 & 198 & .487 \\
Facilities & .984 & 3.215 & 1 & 198 & .075 \\
Cleanliness & .998 & .413 & 1 & 198 & .521 \\
Transportation Infrastructure & .984 & 3.271 & 1 & 198 & .072 \\
Communication infrastructure & .997 & .560 & 1 & 198 & .455 \\
Accomodation infrastructure & 1.000 & .008 & 1 & 198 & .928 \\
\hline
\end{tabular}

Based on the analysis of Table 3, there are 23 tourism mix variables used to differentiate the considerations of visitors who visit natural attractions and those who visit artificial attractions. From the 23 tourism mix variables used to differentiate, there are only 5 variables that can be used to differentiate the considerations of visitors traveling to natural tourism objects and those visiting artificial tourism objects, they are: beauty, coolness, uniqueness, advertisements, promotions, with a level of sig. $\leq 0.05$. However, to ensure the correctness in discriminant analysis, all variables are included for further processing using the Stepwise method.

Table 4 presents the independent variables used to differentiate two categories, they are tourists who choose natural tourism objects and tourists who choose artificial tourism objects. Based on the output variables entered / 
removed, there are 9 variables that can be used to differentiate tourist considerations in choosing the type of tourism objects, namely: coolness, advertisement, facility, price, location, travel agency, attraction, transportation infrastructure, and public hospitality. Therefore, the behavior of visitors who travel to natural attractions and visitors who visit artificial attractions is influenced by respondents' attitudes toward the variables of coolness, advertisement, facility, price, location, travel agency, attraction, transportation infrastructure, and public hospitality.

Table 4. Variable entered/removed

\begin{tabular}{|c|c|c|c|c|c|c|c|}
\hline \multirow[t]{2}{*}{ Step } & \multirow[t]{2}{*}{ Entered } & \multirow[t]{2}{*}{ Statistic } & \multirow[t]{2}{*}{ Between Groups } & \multicolumn{4}{|c|}{$\begin{array}{l}\text { Min. D Squared } \\
\text { Exact F }\end{array}$} \\
\hline & & & & Statistic & df1 & df2 & Sig. \\
\hline 1 & Coolness & .348 & Natural and Artificial & 17.387 & 1 & 198.000 & $4.557 \mathrm{E}-5$ \\
\hline 2 & Advertisement & .903 & Natural and Artificial & 22.463 & 2 & 197.000 & $1.629 \mathrm{E}-9$ \\
\hline 3 & Facility & 1.084 & Natural and Artificial & 17.885 & 3 & 196.000 & $2.66 \mathrm{E}-10$ \\
\hline 4 & Price & 1.343 & Natural and Artificial & 16.539 & 4 & 195.000 & $1.09 \mathrm{E}-11$ \\
\hline 5 & Location & 1.571 & Natural and Artificial & 15.390 & 5 & 194.000 & $9.72 \mathrm{E}-13$ \\
\hline 6 & Travel Agency & 1.748 & Natural and Artificial & 14.200 & 6 & 193.000 & $2.23 \mathrm{E}-13$ \\
\hline 7 & Atraction & 1.919 & Natural and Artificial & 13.295 & 7 & 192.000 & $6.07 \mathrm{E}-14$ \\
\hline 8 & Transportation infrastructure & 2.114 & Natural and Artificial & 12.748 & 8 & 191.000 & $1.24 \mathrm{E}-14$ \\
\hline 9 & Public Hospitality & 2.304 & Natural and Artificial & 12.280 & 9 & 190.000 & $3.03 \mathrm{E}-15$ \\
\hline
\end{tabular}

Table 5. Structure Matrix

\begin{tabular}{|c|c|}
\hline \multirow{2}{*}{ Variables } & Function \\
\hline & 1 \\
\hline Coolness & .389 \\
\hline Advertisement & -.278 \\
\hline Price & .235 \\
\hline Beauty $^{a}$ & .178 \\
\hline Transportation Infrastructure & .169 \\
\hline Facility & -.167 \\
\hline Communication Infrastructure & .159 \\
\hline Public Hospitality & .151 \\
\hline Atraction & -.143 \\
\hline Experience $^{a}$ & -.131 \\
\hline Cleanliness $^{\mathrm{a}}$ & .122 \\
\hline Location & -.110 \\
\hline Connection $^{\mathrm{a}}$ & -.077 \\
\hline Accomodation Infrastructure $^{\mathrm{a}}$ & .075 \\
\hline $\operatorname{Cost}^{\mathrm{a}}$ & .075 \\
\hline Hospitality $^{\mathrm{a}}$ & .072 \\
\hline Promotion $^{\mathrm{a}}$ & -.066 \\
\hline Travel Agency & .065 \\
\hline Completeness $^{\mathrm{a}}$ & .052 \\
\hline Package $^{a}$ & -.0232 \\
\hline Nearness $^{\mathrm{a}}$ & -.020 \\
\hline Uniqueness $^{\mathrm{a}}$ & -.006 \\
\hline Safety $^{\mathrm{a}}$ & .003 \\
\hline
\end{tabular}


The structure matrix table contains the loading value of the structure coefficient value indicating the contribution of each variable to form discriminant function. In this study the coolness variable is the variable that most differentiate the attitude of visitors in choosing natural tourism objects and artificial tourism objects because it has the greatest value of the function that is equal to 0.759 . Then, the second variable that most differentiates is the price with a function value of 0.458 . Travel agency availability variable becomes the third variable that can differentiate the attitude of visitors in choosing natural tourism objects and artificial tourism objects because the variable function value is 0.445 . The transportation facility and infrastructure variable becomes the fourth variable that can differentiate the attitude of visitors in choosing tourism objects with a value of 0.420 function. The variable of public hospitality becomes the fifth variable that can differentiate the attitude of visitors in choosing attractions with a value of 0.373 function. The location variable becomes the sixth variable that can differentiate with the function value of -0.490 . The facility variable becomes the seventh variable that can differentiate the attitude of visitors in choosing tourism objects with a value of $-0,521$ function. Furthermore, the attraction variable and the advertisement variable become the eighth and ninth variables that can differentiate the attitude of visitors in choosing tourism objects with the value of functions in sequence, -0.521 and -0.812 .

Table 6. Interpretation of the Discriminant

\begin{tabular}{cccc}
\hline Variable & $\begin{array}{c}\text { Artificial Tourism Object } \\
\text { (The Village) } \\
\text { Average }\end{array}$ & $\begin{array}{c}\text { Natural Tourism Object } \\
\text { (Baturraden) } \\
\text { Average }\end{array}$ & $\begin{array}{c}\text { Structure Matrix } \\
\text { Function }\end{array}$ \\
\hline Coolness & 5,5000 & $6,2000^{*}$ & 0,759 \\
Price & 4,9000 & $5,4800^{*}$ & 0,458 \\
Location & $5,5600^{*}$ & 5,3100 & $-0,490$ \\
Advertisement & $4,4800^{*}$ & 3,8500 & $-0,812$ \\
Public Hospitality & 5,2100 & $5,5100^{*}$ & 0,373 \\
Atraction & $4,7500^{*}$ & 4,4100 & $-0,522$ \\
Travel Agency & 4,0100 & $4,1700^{*}$ & 0,445 \\
Facility & 5,8700 & 5,5600 & $-0,521$ \\
Transportation Infrastructure & 5,2400 & $5,6000^{*}$ & 0,420 \\
\hline
\end{tabular}

Based on Table 6, it can be interpreted that tourists who choose natural tourism objects have more positive attitude or are more concerned with the variables of coolness, price, public hospitality, the existence of a travel agency, and the availability of transportation infrastructure. On the other hand, tourists who choose to visit artificial tourism objects have more positive attitude towards location, advertisements, tourist attractions, facilities variables.

Table 7. Result of Function at Group Centroid

\begin{tabular}{cc}
\hline Variabeles & Function \\
\hline Tourism Object & 1 \\
Artificial Tourism Object (The Village) & -.759 \\
Natural Tourism Object (Baturraden) & .759 \\
\hline
\end{tabular}

Table 7 shows the function at group centroid is used to determine the cutoff value which is the boundary value where the predicted value must be included in the category of artificial tourism objects, The Village or natural tourism objects, Baturraden.

Table 8. Result of Wilks' Lambda

\begin{tabular}{ccccc}
\hline Test of Funtion(s) & Wilks' Lamda & Chi-Square & df & Sig. \\
\hline 1 & .632 & 88.720 & 9 & .000 \\
\hline
\end{tabular}

Based on the Wilks' Lambda, the output is 0.632 or equal to Chi-Square 88,720 with a significance value of 
0,000 . This shows a significant difference (real) between the average value of discriminant scores forboth groups of visitors in choosing natural tourism objects and artificial tourism objects. So, it can be concluded that there are indeed differences in attitudes between groups who choose natural tourism and who choose artificial tourism.

Table 9. Result of Eigenvalues

\begin{tabular}{ccccc}
\hline Function & Eigenvalue & $\%$ of Variance & Cumulative $\%$ & Canonical Correlation \\
\hline 1 & $.582 \mathrm{a}$ & 100.0 & 100.0 & .606 \\
\hline
\end{tabular}

The Eigenvalues table shows the amount of Canonical Correlation, is 0.606. So the size of Square Canonical Correlation is 0.3672 , which can be obtained from (0.606) 2. That is, $36.72 \%$ of the variance of the variable attitude of tourists in choosing tourism object can be explained by the discriminant model formed by nine variables namely coolness, advertisement, facility, price, location, travel agency, attraction, transportation infrastructure, and public hospitality.

Table 10. Result of Classification Function Coefficients

\begin{tabular}{ccc}
\hline Variables & \multicolumn{2}{c}{ Tourism Objects } \\
\cline { 2 - 3 } & Artificial & Natural \\
\hline Coolness & 2.190 & 3.160 \\
Price & .426 & .854 \\
Location & .669 & .171 \\
Advertisement & .191 & -.634 \\
Public Hospitality & .574 & 1.007 \\
Atraction & -.213 & -.719 \\
Travel Acency Availability & .383 & .799 \\
Facility & 2.433 & 1.787 \\
Transportation Infrastructure & .071 & .524 \\
(Constant) & -19.131 & -21.352 \\
\hline
\end{tabular}

Table 10 shows the equality of discriminant that is formed in the visitor who chooses the artificial tourism object, The Village and natural tourism project, Baturraden. Based on this output the equation can be written as follows:

$\mathrm{Y}_{\text {(The Village) }}=-19,131+2,190$ coolness $+0,426$ price $+0,669$ location $+0,191$ advertisement $+0,574$ public hospitality $-0,213$ atraction $+0,383$ travel agency $+2,433$ facility $+0,071$ transportation infrastructure

$\mathrm{Y}_{\text {(Baturaden) }}=-21,352+3,160$ coolness $+0,854$ price $+0,171$ location $-0,634$ advertisement $+1,007$ public hospitality $-0,719$ atraction $+0,799$ travel agency $+1,787$ facility $+0,524$ transportation infrastructure

Table 11. Result of Classification Results

\begin{tabular}{cccccc}
\hline & \multirow{2}{*}{ Tourism Object } & \multicolumn{3}{c}{ Predicted Group Membership } \\
\cline { 3 - 6 } Original & & The Village & Lokawisata Baturraden & Total \\
\hline \multirow{2}{*}{ Count } & The Village & 80 & 20 & 100 \\
& & Lokawisata Baturraden & 24 & 76 & 100 \\
& \multirow{2}{*}{$\%$} & The Village & 80.0 & 20.0 & 100.0 \\
& & Lokawisata Baturraden & 24.0 & 76.0 & 100.0 \\
Cross-validated $^{\text {a }}$ & \multirow{2}{*}{ Count } & The Village & 78 & 22 & 100 \\
& & Lokawisata Baturraden & 25 & 75 & 100 \\
& \multirow{2}{*}{$\%$} & The Village & 78.0 & 22.0 & 100.0 \\
& & Lokawisata Baturraden & 25.0 & 75.0 & 100.0 \\
\hline
\end{tabular}


Classification results table was used to determine the level of accuracy and stability of the formed discriminant model (godness of fit). Based on the table, it shows 78.0 \% means that from 200 data processed, $78.0 \%$ have been entered into the right group, while the cross validation of $76.5 \%$ is higher than $50 \%$, then the model discriminant that has been formed is declared fit or appropriate to be used to differentiate the attitude of tourists in choosing natural tourism objects and those who choose artificial tourism objects.

\section{Conclusion}

Based on the conducted discriminant analysis, there are nine variables that differentiate tourists' considerations in choosing natural and artificial tourism. These variables are coolness, advertisement, facility, price, location, travel agency, attractions, transportation infrastructure, and public hospitality. Tourists who chose natural tourism objects have more positive attitude or are more concerned with the variables of coolness, price, public hospitality, the existence of a travel agency, and the availability of transportation infrastructure, while tourists who chose to visit artificial tourism objects have a more positive attitude or are more concerned with variables location, advertisement, tourist attractions, and completeness of the facilities.

Based on these conclusions, several recommendations for managers of natural tourist attractions could be formulated to pay more attention to the coolness variable by maintaining the authenticity of nature, the price offered is an affordable price for tourists for all levels, public hospitality by providing tourism awareness training for the surrounding community, the existence of a travel agency by establishing cooperation with various travel agencies, and the availability of transportation infrastructure by providing transportation facilities and infrastructure. At the same time, the management of artificial tourism objects has to pay more attention to location variable by choosing strategic and easily accessible locations, advertising variable by making attractive advertising media, especially advertising through social media; tourist attractions variable by always providing innovative and unique tourist attractions compared to tourist artificial attractions; complete facilities variable by completing various clean and comfortable tourist facilities such as toilets, prayer rooms, cafes, parking lots, banking access, and health access.

\section{Acknowledgements}

Thank you to the Ministry of Technology Research and Higher Education who have provided research funding through the Professor Facilitating Research Scheme, the Institute of Research and Community Service of Jenderal Soedirman University.

\section{References}

Abuamoud, I. N., Libbin, J., Green, J., \& ALRousan, R. (2014). Factors affecting the willingness of tourists to visit cultural heritage sites in Jordan. Journal of Heritage Tourism, 9(2), 148-165. https://doi.org/10.1080/1743873X.2013.874429

Coban, S. (2012). The effects of the image of destination on tourist satisfaction and loyalty: The case of Cappadocia. European Journal of Social Sciences, 29(2), 222-232. Retrieved from https://www.researchgate.net/publication/267265793_The_Effects_of_the_Image_of_Destination_on_Touri st_Satisfaction_and_Loyalty_The_Case_of_Cappadocia

Dogra, R., \& Gupta, A. (2012). Barriers to community participation in tourism development: Empirical evidence from a rural destination. South Asian Journal of Tourism and Heritage, 5(1), 129-142. Retrieved from https://pdfs.semanticscholar.org/9f50/5492fb7326b52f35674b3f38ddfc57234412.pdf

Hernández-Lobato, L., Solis-Radilla, M. M., Moliner-Tena, M. A., \& Sánchez-García, J. (2006). Tourism destination image, satisfaction and loyalty: a study in Ixtapa-Zihuatanejo, Mexico. Tourism geographies, 8(4), 343-358. https://doi.org/10.1080/14616680600922039

Khuntia, N., \& Mishra, J. M. (2016). The Barriers of Community Participation in Tourism Development in Chilika Lake, Odisha India. Journal of Tourism, 17(2), 83-93.

Khuong, M. N., \& Nguyen, P. A. (2017). Factors affecting tourist destination satisfaction and return intention-a study in Ho Chi Minh City, Vietnam. Journal of Economics, Business and Management, 5(2), 95-102. https://doi.org/10.18178/joebm.2017.5.2.493

Malhotra, N., Hall, J., Shaw, M., \& Oppenheim, P. (2006). Marketing research: An applied orientation. Pearson Education Australia. Retrieved from https://www.academia.edu/33330345/An_Applied_Approach_Marketing_Research_An_Applied_Approach _Updated_Second_European_Edition

Marinao, E. (2017). Determinants of Satisfaction with the Tourist Destination. In Mobilities, Tourism and Travel 
Behavior-Contexts and Boundaries. IntechOpen. https://doi.org/10.5772/intechopen.70343

Mattila, A. S. (2004). Consumer behavior research in hospitality and tourism journals. International Journal of Hospitality Management, 23(5), 449-457. https://doi.org/10.1016/j.ijhm.2004.10.001

Ritsma, N., Hummel, J., \& Gyeltshen, P. (2010). Tourism and payments for environmental services: The outlook for a stronger business case to develop rural tourism in Bhutan. In Mountain Forum Bulletin (Vol. 10, No. 1, pp. 34-37). https://lib.icimod.org/record/14616

Salimov, S. Y. (2018). The Development of Youth Tourism in Uzbekistan. Journal of Tourism \& Hospitality, 7(4). Retrieved from https://www.longdom.org/abstract/the-development-of-youth-tourism-in-uzbekistan-17606.html

Suliyanto. (2013). Financing Model of Coconut Sugar Micro Small and Medium Entreprises (MSMEs) in Indonesia. International Business Management, 7, 410-413. Retrieved from http://medwelljournals.com/abstract/?doi=ibm.2013.410.413

Tosun, C. (2002). Host perceptions of impacts: A comparative tourism study. Annals of tourism research, 29(1), 231-253. https://doi.org/10.1016/S0160-7383(01)00039

Tsiotsou, R. H., Ratten, V., \& Tsiotsou, R. (2010). Future research directions in tourism marketing. Marketing intelligence \& planning. https://doi.org/10.1108/02634501011053702

\section{Copyrights}

Copyright for this article is retained by the author(s), with first publication rights granted to the journal.

This is an open-access article distributed under the terms and conditions of the Creative Commons Attribution license (http://creativecommons.org/licenses/by/4.0/). 